\title{
HUBUNGAN INTELEGENSI DENGAN HASIL BELAJAR MATEMATIKA SISWA KELAS V SD NEGERI 68 PEKANBARU
}

\author{
Zetra Hainul Putra, Wulan Sucitra
}

\begin{abstract}
Abstrak
Banyak faktor yang dapat mempengaruhi prestasi akademik seseorang. Salah satu faktor internal yang dapat mempengaruhi prestasi akademik seseorang adalah intelegensi. Oleh sebab itu, penelitian ini bertujuan untuk mengetahui apakahadahubungan antara intelegensi dengan hasil belajar matematika siswa kelas V SD Negeri 68 Pekanbaru. Metode penelitian yang dipakai dalam penelitian ini adalah metode korelasional dan regresi sederhana. Subjek penelitian ini adalah 33 siswa kelas V SD Negeri 68 Pekanbaru yang terdiri dari 15 perempuan dan 18 laki-laki. Data penelitian ini menggunakan data sekunder berupa data intelegensi dan data hasil rapor terakhir nilai matematika siswa pada semester ganjil dan genap tahun ajaran 2013/2014. Hasil penelitian menunjukkan bahwa terdapat hubungan yang signifikan antara intelegensi dengan hasil belajar matematika yang ditunjukkan dengan semakin tinggi intelegensi yang diberikan maka akan semakin tinggi hasil belajar matematika.
\end{abstract}

Kata Kunci: intelegensi, hasil belajar matematika, korelasi dan regresi.

\section{Pendahuluan}

Perkembangan zaman yang semakin modern terutama pada era globalisasi seperti sekarang ini menuntut adanya sumber daya manusia yang berkualitas tinggi. Peningkatan kualitas sumber daya manusia merupakan prasyarat mutlak untuk mencapai tujuan pembangunan. Salah satu wahana untuk meningkatkan kualitas sumber daya manusia tersebut adalah pendidikan. Pendidikan merupakan suatu aspek kehidupan yang sangat mendasar bagi pembangunan bangsa suatu negara. Dalam penyelenggaraan pendidikan disekolah yang melibatkan guru sebagai pendidik dan siswa 
Zetra Hainul Putra, Wulan Sucitra

sebagai peserta didik, diwujudkan dengan adanya interaksi belajar mengajar atau proses pembelajaran (Iskandar, 2009:141).

Salah satu usaha yang digunakan untuk mewujudkan tujuan tersebut adalah meningkatkan hasil belajar siswa. Prestasi belajar merupakan tolak ukur yang utama untuk mengetahui keberhasilan belajar. Seseorang yang prestasinya tinggi dapat dikatakan bahwa ia telah berhasil dalam belajar. Pengenalan terhadap faktor - faktor yang mempengaruhi prestasi belajar penting sekali artinya dalam rangka membantu murid dalam mencapai prestasi belajar yang sebaik-baiknya (Abu Ahmadi, 2004:138).

Belajar memerlukan kesiapan rohani dan ketenangan dengan baik. Apabila dirinci faktor rohani itu meliputi antara lain ; intelegensi, bakat, minat, motivasi, faktor kesehatan mental dan tipe khusus seorang pelajar (Abu Ahmadi, 2004:138). Dari faktor yang berhubungan dengan intelegensi, masyarakat umum mengenal intelegensi sebagai istilah yang menggambarkan kecerdasan, kepintaran ataupun kemampuan untuk memecahkan masalah yang dihadapi.

Gambaran tentang anak yang berintelegensi tinggi adalah gambaran mengenai siswa yang pintar, siswa yang selalu naik kelas dengan nilai baik, atau siswa yang jempolan dikelasnya. Bahkan gambaran ini meluas pada citra fisik yaitu citra anak yang wajahnya bersih, berpakaian rapi, matanya bersinar, atau berkacamata. Sebaliknya anak yang berintelegensi rendah, dan mulut lebih banyak menganga disertai dengan tatapan bingung. Diantara ciri-ciri perilaku yang secara tidak langsung telah disepakati sebagai tanda telah dimilikinya intelegensi yang tinggi, antara lain adalah adanya kemampuan untuk memahami dan menyelesaikan masalah dengan cepat, kemampuan mengingat, kreativitas yang tinggi, dan imajinasi yang berkembang. Sebaliknya perilaku mental yang sederhana dan semacamnya, dianggap sebagai indikasi tidak dimilikinya intelegensi yang baik. Namun hal ini belumlah jaminan bahwa seorang anak memiliki intelegensi yang tinggi ataupun rendah, karena untuk menentukan intelegensi seseorang itu harus dilakukan tes yaitu tes intelegensi. 
Hubungan Intelegensi dengan Hasil Belajar Matematika Siswa Kelas V SD Negeri 68 Pekanbaru

Dalam bidang akademis, tingkat kecerdasan atau intelegensi (IQ) seorang individu tidak dapat diragukan lagi sangat menentukan tingkat keberhasilan belajar individu tersebut. Semakin tinggi kemampuan intelegensi individu tersebut tersebut maka semakin besar peluangnya untuk meraih sukses dibidang akademis. Sebaliknya, semakin rendah kemampuan intelegensi seorang individu maka semakin kecil peluang untuk meraih sukses dibidang akademis. Sesorang yang mempunyai tingkat intelegensi yang lebih tinggi, akan memiliki prestasi akademik yang lebih baik, lebih mampu mengikuti materi yang diajarkan dan cenderung mendapatkan keberhasilan kerja yang lebih besar.

Intelegensi merupakan salah satu faktor internal yang mempengaruhi prestasi akademik seseorang. Intelegensi sendiri dalam perspektif psikologi memiliki arti yang beraneka ragam. Begitu banyak definisi tentang intelegensi yang dikemukakan oleh para ahli. Definisi intelegensi itu mengalami berbagai perubahan dari waktu ke waktu, tetapi sejak dahulu tidak pernah mengurangi penekanan pada aspek kognitifnya. Salah satu cara yang sering digunakan untuk menyatakan tinggi rendahnya tingkat intelegensi adalah menerjemahkan hasil tes intelegensi ke dalam angka yang dapat menjadi petunjuk mengenai kedudukan tingkat kecerdasan seseorang bila dibandingkan secara relatif terhadap suatu norma. Secara tradisional, angka normatif dari hasil tes intelegensi dinyatakan dalam bentuk rasio (quotient) dan dinamai IQ (intelligence quotient).

Intelegensi sebagai unsur kognitif dianggap memegang peranan yang cukup penting. Bahkan kadang-kadang timbul anggapan yang menempatkan intelegensi dalam peranan yang melebihi proporsi yang sebenarnya. Sebagian orang bahkan menganggap bahwa hasil tes intelegensi yang tinggi merupakan jaminan kesuksesan dalam belajar sehingga bila terjadi kasus kegagalan belajar pada anak yang memiliki IQ tinggi akan menimbulkan reaksi berlebihan berupa kehilangan kepercayaan pada institusi yang menggagalkan anak tersebut atau kehilangan 
kepercayaan pada pihak yang telah memberi diagnosa IQ-nya. Sejalan dengan itu, tidak kurang berbahayanya adalah anggapan bahwa hasil tes IQ yang rendah merupakan vonis akhir bahwa individu yang bersangkutan tidak mungkin dapat mencapai prestasi yang baik. Hal ini tidak saja merendahkan self-esteem (harga diri) seseorang akan tetapi dapat menghancurkan pula motivasinya untuk belajar yang justru menjadi awal dari segala kegagalan yang tidak seharusnya terjadi.

Lukman Gumadi (2012) dalam penelitiannya menyimpulkan adanya hubungan positif dan signifikan antara intelegensi terhadap prestasi akademik taruna Jurusan Nautika di Sekolah Tinggi Ilmu Pelayaran Jakarta, semakin tinggi intelegensiyang dimiliki maka akan semakin tinggi prestasi akademik mereka.

Hasil yang serupa dijumpai dalam penelitian yang dilakukan $\mathrm{Ni}$ Kadek Sukiarti (2009) pada sampel penelitian sebanyak 180 orang siswa. Pada penelitiannya menunjukkan bahwa terdapat hubungan positif yang signifikan antara intelegensi dengan prestasi akademik. Diperoleh bahwa secara parsial intelegensi dan motivasi belajar berpengaruh sangat nyata terhadap prestasi akademik dan konstribusi (sumbangan) dari variabel intelegensi yang cukup besar. Hal ini terjadi karena seseorang yang memiliki intelegensi baik (IQ-nya tinggi) umumnya mudah belajar dan hasilnya pun cenderung baik. Sebaliknya orang yang intelegensinya rendah cenderung mengalami kesukaran dalam belajar, lambat berpikir, sehingga prestasi akademiknya pun rendah. Namun, kontribusi intelegensi terhadap prestasi akademik cukup rendah pada penelitian yang dilakukan Malik (2002) dan berbeda dengan Ali Khomsan dalam Roida Eva (2013) yang berpendapat bahwa anak dengan prestasi yang baik, saat diuji inteligensinya hanya mendapatkan skor biasa-biasa saja karena kondisi fisik dan psikologis individu sewaktu dikenai tes akan banyak berpengaruh pada hasil tesnya.

Dari uraian tersebut, peran intelegensi dalam hal prestasi belajar seseorang disekolah sangatlah penting dan cukup berpengaruh, untuk itu peneliti tertarik untuk mengetahui apakah benar ada hubungan antara 
Hubungan Intelegensi dengan Hasil Belajar Matematika Siswa Kelas V SD Negeri 68 Pekanbaru

intelegensi dengan hasil belajar. Dalam hal ini peneliti menentukan sampel penelitian yaitu siswa kelas V SDN 68 Pekanbaru yang memiliki prestasi belajar yang bervariatif.

Berdasarkan pengamatan secara langsung dan informasi dari guru yang merupakan wali kelas tersebut, ditemukan masih banyak masalah yang terjadi dikelas salah satunya siswa yang tidur pada saat proses belajar mengajar di kelas, kurang memiliki inisiatif untuk belajar mandiri atau berdiskusi dengan teman-temannya. Tingkat intelegensi siswa diketahui peneliti melalui hasil tes intlegensi yang dilakukan oleh psikolog sebelumnya. Namun dari hasil tes intelegensi tersebut dapat dilihat hasil yang sangat bervariatif dan diikuti juga oleh hasil belajar siswanya yang jauh berbeda dari masing-masing siswa. Karena intelegensi merupakan kemampuan sesorang memecahkan masalah dan berfikir secara rasional, maka penelitian ini dihubungkan dengan prestasi belajar pada mata pelajaran matematika yang merupakan mata pelajaran yang dianggap siswa paling sulit. Oleh sebab itu, perlu diadakan penelitian tentang hubungan antara tingkat intelegensi dengan hasil belajar matematika siswa kelas $\mathrm{V}$ SDN 68 Pekanbaru.

\section{Metode Penelitian}

Jenis penelitian yang digunakan dalam penelitian ini adalah metode korelasional dan regresi sederhana. Penelitian dilaksanakan pada bulan November sampai bulan Desember 2013 di SDN 68 Pekanbaru yang terletak di kelurahan Kampung Melayu, Kecamatan Sukajadi, Provinsi Riau, tepatnya di Jalan Pepaya. Populasi dalam penelitian ini seluruh siswa kelas V SDN 68 Pekanbaru dan sampel sebanyak 33 siswa. Variabel dalam penelitian ini adalah tingkat intelegensi (variabel bebas) dan hasil belajar matematika (variabel terikat).

Instrumen penelitian yaitu soal tes intelegensi menggunakan tes WISC (Wechsler Intelligence Scale for Children) yang telah terstandardisasi yang dilakukan oleh psikolog pada tanggal 24 April 2014 di kelas V SDN 68 
Pekanbaru. Data diperoleh dengan melakukan subtes verbal (kosakata, informasi, berhitung, dan deret angka) dan subtes performansi (menyusun gambar, desain balok, coding, dan maze). Untuk hasil belajar matematika data dikumpulkan dengan menggunakan metode dokumentasi diukur berdasarkan rata-rata nilai raport siswa pada semester terakhir yang telah dilalui subjek penelitian yaitu pada semester genap dan ganjil.

Data dalam penelitian ini berupa data sekunder yaitu data skor intelegensi siswa yang diperoleh dari tes soal intelegensi yang telah dilakukan sebelumnya kepada siswa yang menjadi sampel dan data hasil belajar matematika siswa yang didapat dari nilai rapor siswa SDN 68 Pekanbaru. Keseluruhan analisis data diuji dengan menggunakan bantuan komputer melalui program microsoft excel. Data yang dikumpul kemudian diolah dan disajikan dalam bentuk tabel distribusi frekuensi, data tersebut diuji normalitasnya terlebih dahulu kemudian ditentukan koefisien korelasinya dan untuk pengujian hipotesis pada penelitian ini menggunakan analisis regresi sederhana yaitu untuk melihat hubungan intelegensi dengan prestasi belajar matematika. Besarnya hubungan kedua variabel dinyatakan dengan koefisien korelasi dengan uji pearson. Besarnya koefisien korelasi antar dua variabel diuji keberartiannya untuk mengetahui apakah koefisien korelasi yang dihasilkan signifikan atau tidak, maka digunakan uji t karena hasilmya signifikan maka besarnya pengaruh antar variabel dicari dengan koefisien determinasi.

Berdasarkan landasan teori sebagaimana dikemukakan di atas, maka hipotesis penelitian dapat dirumuskan sebagai berikut:

Hipotesis:

$\mathrm{H}_{0} \quad$ Diduga tidak terdapat hubungan antara intelegensi dengan hasil belajar matematika.

$\mathrm{H}_{1} \quad$ Diduga terdapat hubungan antara intelegensi dengan hasil belajar matematika. 
Hubungan Intelegensi dengan Hasil Belajar Matematika Siswa Kelas V SD Negeri 68 Pekanbaru

\section{Hasil dan Pembahasan}

\section{A. Deskripsi data}

Setelah data variabel bebas dan variabel terikat diperoleh, kemudian diolah dengan menggunakan perhitungan microsoft excel, maka diperoleh hasil uji statistik deskriptif yang terdiri :

1. Deskripsi data Intelegensi

Variabel intelegensi mempunyai mean atau rata-rata hitung sebesar 101,45 dan simpangan bakunya 9,98. Dari perhitungan variabel tingkat intelegensi pada 33 orang siswa SDN 68 Pekanbaru didapat skor minimal 85 dan skor tertinggi 118 sehingga diperoleh range $118-85=33$. Selanjutnya hasil distribusi frekuensi skor intelegensiadalah sebagai berikut :

Tabel 1. Distribusi Intelegensi

\begin{tabular}{|c|c|}
\hline Skor IQ & Frekuensi \\
\hline $85-90$ & 6 \\
\hline $91-96$ & 5 \\
\hline $97-102$ & 7 \\
\hline $103-108$ & 4 \\
\hline $109-114$ & 6 \\
\hline $115-120$ & 5 \\
\hline Jumlah & 33 \\
\hline
\end{tabular}

2. Deskripsi data hasil belajar matematika

Variabel hasil belajar matematika mempunyai mean atau rata-rata hitung sebesar 77,06 dan simpangan bakunya 7,10. Dari perhitungan variabel hasil belajar matematika siswa kelas V SDN 68 Pekanbaru didapat skor minimal 65 dan skor tertinggi 86 sehingga diperoleh range 86-65 = 21. Selanjutnya hasil distribusi frekuensi nilai matematika adalah sebagai berikut : 
Zetra Hainul Putra, Wulan Sucitra

Tabel 2. Distribusi hasil belajar matematika

\begin{tabular}{|c|c|}
\hline Nilai & Frekuensi \\
\hline $65-68$ & 7 \\
\hline $69-72$ & 4 \\
\hline $73-76$ & 5 \\
\hline $77-80$ & 2 \\
\hline $81-84$ & 9 \\
\hline $85-88$ & 6 \\
\hline Jumlah & 33 \\
\hline
\end{tabular}

\section{B. Analisis data}

1. Uji validitas dan reliabelitas

Karena data skor intelegensi didapat dari hasil tes yang dilakukan oleh psikolog dengan menggunakan tes WISC (Wechsler Intelligence Scale for (hildren) yang sudah terstandardisasi maka soal ini sudah teruji validitas dan reliabelitasnya.

2. Uji normalitas dan linearitas

Untuk uji normalitas sebaran data digunakan ujililliefors, Berdasarkan pengujian normalitas pada variabel tingkat intelegensi diperoleh $\mathrm{L}_{\text {maks }}$ sebesar 0,14 dan $\mathrm{L}_{\text {tabel }}$ sebesar 0,156 . Hal ini menunjukkan bahwa distribusi data tes IQ untuk variabel tingkat intelegensi berdistribusi normal. Dan data hasil belajar matematika diperoleh $L_{\text {maks }}$ sebesar 0,14 dan $\mathrm{L}_{\text {tabel }}$ sebesar 0,156 yang menunjukkan data berdistribusi normal.

3. Uji Korelasi dan uji hipotesis

Sebelum melakukan uji hipotesis, peneliti melakukan uji korelasi terlebih dahulu sebagai prasyarat dari uji regresi. Uji korelasi ini digunakan untuk mengetahui tingkat (derajat) keeratan hubungan antara variabel bebas dengan variabel terikat, semakin besar korelasi maka semakin kuat hubungannya. Dari hasil perhitungan korelasi pearson didapat nilai koefisien korelasi sebesar 0,75. Dari hasil tersebut tampak bahwa hubungan antara intelegensi dan hasil belajar matematika kuat dan searah (positif). 
Hubungan Intelegensi dengan Hasil Belajar Matematika Siswa Kelas V SD Negeri 68 Pekanbaru

$t_{\text {hitung }}=6,35$ dan $t_{\text {tabel }}=2,03$, Karena $t_{\text {hitung }}(6,35)$ lebih besar dari $t_{\text {tabel }}(2,03)$ maka $\mathrm{H}_{0}$ ditolak dan $\mathrm{H}_{1}$ diterima sehingga disimpulkan terdapat korelasi positif yang signifikan antara intelegensi dengan hasil belajar matematika siswa SDN 68 Pekanbaru.

4. Uji regresi

Analisis data yang digunakan untuk menguji hipotesis dalam penelitian ini adalah dengan menggunakan teknik analisis regresi sederhana yang bertujuan untuk mengetahui ada atau tidaknya kelinieran antara variabel bebas dengan variabel terikat. Berdasarkan hasil perhitungan yang dilakukan diperoleh a sebesar 22,74 dan b sebesar 0,535 bentuk persamaan regresi linear sederhana sebagai berikut: $\hat{\boldsymbol{Y}}=22,74+0,535 \mathrm{X}$. Dari persamaan regresi tersebut terlihat bahwa pengaruh intelegensidengan hasil belajar matematika siswa SDN 68 Pekanbaru adalah searah (positif), hal tersebut ditunjukkan pada koefisien regresi atau nilai $b$ dalam persamaan regresi tersebut yang menunjukkan angka positif sebesar 0,535 yang mengandung arti bahwa setiap kenaikan intelegensil satuan akan diikuti dengan kenaikan nilai matematika siswa SDN 68 Pekanbaru sebesar 0,535 satuan. Demikian pula sebaliknya, jika intelegensi mengalami penurunan 1 satuan maka nilai matematika akan cenderung mengalami penurunan sebesar 0,535 satuan. Dan nilai koefisien a (intercept) adalah sebesar 22,74 yang mempunyai arti apabila tidak terdapat intelegensi $(X=0)$, diperkirakan hasil belajar matematika siswa SDN 68 Pekanbaru sebesar 22,74 satuan.

Hasil Belajar

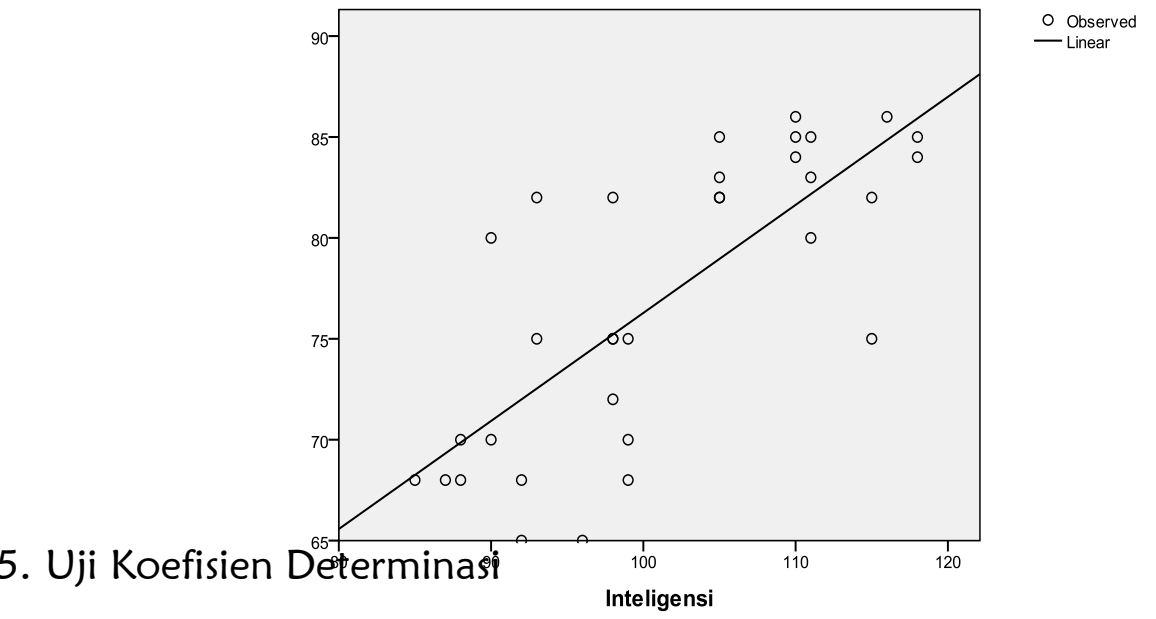


Dengan melihat hasil perhitungan koefisien determinasi yaitu 0,566 atau $56,6 \%$, hal ini menunjukkan besarnya pengaruh positif dari intelegensi terhadap hasil belajar matematika sebesar $56,6 \%$ sedangkan sisanya $43,4 \%$ merupakan pengaruh dari faktor lain.

\section{Pembahasan}

Berdasarkan hasil penelitian pada siswa kelas V SDN 68 Pekanbaru dari jumlah sampel sebanyak 33 orang ditemukan siswa yang memiliki tingkat IQ dibawah rata-rata berjumlah 6 orang, berdasarkan tabel tingkat sekolah dibawah rata-rata ini artinya dapat menyelesaikan sekolah dasar. Pada klasifikasi rata-rata berjumlah 16 orang artinya dapat menyelesaikan sekolah lanjutan dan diatas rata-rata berjumlah 11 orang berarti dapat menyelesaikan sekolah lanjutan tanpa kesulitan. Hal ini sesuai dengan tabel klasifikasi tingkatan IQ menurut William Stern (Desmita, 2010).

Dari hasil penelitian dengan menggunakan uji pearson antara intelegensi dengan hasil belajar matematika diperoleh besarnya koefisien korelasi yaitu 0,752 berarti hubungan intelegensi dengan hasil belajar matematika siswa kelas V SDN 68 Pekanbaru adalah kuat dan searah (positif). Dari tabel distribusi $t$, diperoleh $t_{\text {hitung }}=6,35$ dan $t_{\text {tabel }}=2,03$, Karena $t_{\text {hitung }}(6,35)$ lebih besar dari $t_{\text {tabel }}(2,03)$ maka $H_{0}$ ditolak dan $H_{1}$ diterima sehingga disimpulkan terdapat korelasi positif yang signifikan antara intelegensi $(\mathrm{X})$ dengan hasil belajar matematika $(\mathrm{Y})$ siswa SDN 68 Pekanbaru. Hasil ini didukung oleh penelitian yang dilakukan oleh NI Kadek Sukiarti (2009), pada penelitian yang dilakukannya pada sampelsebanyak 180 orang siswayang menunjukkan bahwa terdapat hubungan positif yang signifikan antara intelegensi dengan prestasi akademik. Pada penelitiannya diperoleh bahwa secara parsial intelegensi dan motivasi belajar berpengaruh sangat nyata terhadap prestasi akademik. Hal ini dibuktikan dari nilai $t_{\text {hitung }}>t_{\text {tabel. }}$ Ini terjadi karena kualitas intelegensi atau kecerdasan yang tinggi merupakan faktor yang 
Hubungan Intelegensi dengan Hasil Belajar Matematika Siswa Kelas V SD Negeri 68 Pekanbaru

mempengaruhi keberhasilan individu dalam belajar dan meraih kesuksesan dalam hidupnya. Dan terbukti dari hasil penelitian ini bahwa IQ mempunyai peranan dan hubungan yang penting dalam meraih prestasi belajar di sekolah.

Dari persamaan regresi linier sederhana $\hat{\gamma}=22,74+0,535 X$ terlihat bahwa pengaruh intelegensidengan hasil belajar matematika siswa SDN 68 Pekanbaru adalah searah (positif), hal tersebut ditunjukkan pada koefisien regresi atau nilai $b$ dalam persamaan regresi tersebut yang menunjukkan angka positif sebesar 0,535 yang mengandung arti bahwa setiap kenaikan intelegensil satuan akan diikuti dengan kenaikan nilai matematika siswa SDN 68 Pekanbaru sebesar 0,535 satuan. Demikian pula sebaliknya, jika intelegensi mengalami penurunan 1 satuan maka nilai matematika akan cenderung mengalami penurunan sebesar 0,535 satuan. Dan nilai koefisien a (intercept) adalah sebesar 22,74 yang mempunyai arti apabila tidak terdapat intelegensi $(X=0)$, diperkirakan hasil belajar matematika siswa SDN 68 Pekanbaru sebesar 22,74 satuan. Hasil perhitungan regresi sederhana pada penelitian ini juga sesuai dengan penelitian yang dilakukan Ni Kadek Sukiarti (2009), dimana persamaan regresi linear pada variabel intelegensi terhadap prestasi akademik memiliki pengaruh searah dan positif. Hasil yang serupa juga dijumpai pada penelitian yang dilakukan oleh Lukman Gunadi (2012). Dari persamaan regresi yang diperoleh terlihat bahwa pengaruh intelegensidengan prestasi akademik pada sampel adalah searah (positif), hal tersebut ditunjukkan pada koefisien regresi atau nilai b1 dalam persamaan regresi tersebut yang menunjukkan angka positif, yang mengandung arti bahwa setiap kenaikan intelegensi satu satuan akan diikuti dengan kenaikan prestasi akademik. Demikian pula sebaliknya, jika intelegensi mengalami penurunan 1 satuan maka prestasi akademik akan cenderung mengalami penurunan. Hal ini terjadi karena intelegensi merupakan kemampuan seseorang dalam memecahkan masalah, masalah ini bisa berbentuk soal-soal yang perlu pemahaman seseorang untuk mnyelesaikannya. Maka dari itu, semakin 
tinggi taraf IQ seseorang maka akan semakin cepat dan mudah untuk mencapai prestasi belajarnya di sekolah contohnya pada nilai matematikanya akan mendapat nilai yang tinggi pula. Sedangkan seseorang yang memiliki taraf IQ yang rendah maka akan cenderung sulit dan lama untuk mempelajari dan memahami sesuatu hal termasuk pada pelajaran matematika.

Besarnya konstribusi (sumbangan) dari variabel intelegensi adalah $56,6 \%$ sedangkan sisanya $43,4 \%$ merupakan pengaruh dari faktor lain. Hal ini sesuai dengan pendapat Saifuddin Azwar dalam Ni Kadek Sukiarti (2009) yang menyebutkan bahwa intelegensi merupakan salah satu faktor internal yang mempengaruhi prestasi akademik seseorang. Pendapat tersebut sejalan dengan penelitian ini bahwa IQ mempunyai peranan dan hubungan yang penting dalam meraih prestasi belajar disekolah, namun masih ada faktor-faktor lain yang mempengaruhi prestasi belajar seseorang seperti faktor emosional dan faktor lainnya. Namun berbeda dengan Malik (2002) dalam penelitiannya memperoleh kontribusi intelegensi terhadap prestasi akademik hanya sebesar $8 \%$ pada 83 orang siswa kelas I dan II SMUN di wilayah Jakarta Timur yang berpartisipasi dalam kegiatan KIR dan sisanya adalah faktor lain. Hal ini bisa saja terjadi karena semakin besar seseorang atau semakin tinggi usia maka IQ semakin tidak mempengaruhi hasil belajar seseorang. Menurut Irfan, dkk dalam Ni Kadek Sukiarti (2009), berbagai penelitian memang menunjukkan adanya hubungan yang jelas antara IQ dengan prestasi belajar disekolah, pengaruh IQ pada prestasi belajar berkisar antara 16 sampai 25 persen. Oleh karena itu variabel intelegensi memiliki pengaruh yang cukup tinggi terhadap prestasi akademik. Namun dalam penelitian ini menunjukkan bahwa intelegensi mempengaruhi lebih dari $50 \%$. Hal tersebut dapat saja terjadi dan bisa berubah dengan meningkatnya usia dan kematangan siswa.

Berdasarkan uraian diatas, dapat disimpulkan bahwa intelegensi merupakan salah satu faktor yang dapat mempengaruhi prestasi akademik seseorang. Seseorang yang memiliki IQ yang tinggi umumnya mudah 
Hubungan Intelegensi dengan Hasil Belajar Matematika Siswa Kelas V SD Negeri 68 Pekanbaru

belajar dan hasilnya pun cenderung baik. Sebaliknya orang yang intelegensinya rendah cenderung mengalami kesukaran dalam belajar, lambat berpikir, sehingga prestasi akademiknya pun rendah. Hasil penelitian ini juga menunjukkan subjek dalam penelitian ini memiliki tingkat intelegensi yang tergolong rata-rata bahkan juga memiliki tingkat prestasi akademik pada pelajaran matematika yang cukup tinggi.

Hasil penelitian ini berbeda dengan Ali Khomsan dalam Roida Eva (2013), yang berpendapat bahwa anak dengan prestasi yang baik, saat diuji inteligensinya hanya mendapatkan skor biasa-biasa saja. Karena IQ yang diperoleh seseorang dari tes intelegensi pada suatu waktu tidaklah menjadi label yang selalu melekat bagi dirinya. Kondisi fisik dan psikologis individu sewaktu dikenai tes akan banyak berpengaruh pada hasil tesnya. Bila individu yang dites sedang dalam kelabilan emosi, sedang tidak siap atau sedang dalam kondisi lelah secara fisik maka hasil tes intelegensi tidaklah akan memberi informasi yang benar mengenai kapasitas intelektualnya. Kalaupun hasil tes intelegensi telah dapat memberikan informasi yang tepat mengenai kapasitas intelektual individu, namun daya prediksinya terhadap performansi masih tergantung pada berbagai variabel lain. IQ yang tinggi misalnya, dalam bidang pendidikan biasanya memberikan prediksi terhadap prestasi belajar yang baik. Tetapi apakah individu yang memilki IQ tinggi, masih tergantung pada faktor-faktor lain semisal motivasi belajar dan faktor peluang. Hasil tes integensi yang tinggi sebenarnya tidak menjanjikan apaapa selama tidak ditopang oleh faktor lain yang kondusif. Sebaliknya hasil pengukuran intelegensi yang tidak dapat dianggap sebagai vonis yang mematikan harapan dan usaha untuk berprestasi.

Jadi, IQ tinggi bukan jaminan untuk mencapai prestasi luar biasa di sekolah. Hal ini juga didukung penelitian sebelumnya yang menunjukkan bahwa ada faktor-faktor lain yang mempengaruhi prestasi akademik. Seperti yang diungkap oleh Tarmidi (Ni Kadek Sukiarti, 2009) yang mengatakan bahwa iklim kelas berkorelasi positif dengan perubahan tingkah laku dan prestasi hasil pembelajaran siswa. Dengan kata lain, iklim 
kelas merupakan salah satu cara untuk meningkatkan efektifitas dan kualitas pembelajaran di kelas. Iklim kelas merupakan faktor ekternal yang dapat mempengaruhi prestasi akademik siswa. Iklim kelas sendiri meliputi ruangan kelas, lingkungan kelas dan lain-lain. Didukung oleh Andreu (Malik,2002) menyimpulkan bahwa ada hubungan antara sikap dan intelegensi terhadap peningkatan prestasi belajar, tetapi juga ada variabel-variabel lain yang dapat meningkatkan prestasi belajar selain intelegensi.

Dari uraian diatas disimpulkan bahwa tes intelegensi adalah: (1) bukan merupakan tes untuk pengukuran kemampuan bawaan, tes intelegensi sebenarnya mengukur performansi individu pada suatu tugas mental tertentu. Tugas-tugas dalam tes intelegensi dipengaruhi oleh pengalaman disekolah dan dari lingkungan kehidupan sehari-hari. Kemampaun untuk menjawab soal-soal dan pertanyaan dalam tes intelegensi banyak tergantung pada pengalaman dan berbagai faktor lain yang dipelajari sehari-hari. (2) bukan merupakan tes untuk prediksi dari hasil tes intelegensi yang akurat. Sebagaimana telah dikemukakan hasil pengukuran intelegensi tidak menjanjikan apa-apa selama tidak didukung oleh faktor lain yang relevan. (3) bukan merupakan tes untuk mengungkapkan semua informasi mengenai kompetensi potensial dan aktual yang dimiliki siswa dan kemampuannya sebagai manusia. Memang hasil tes dapat memberi gambaran mengenai kelemahan dan kekuatan di berbagai bidang yang dimiliki sesorang. Tes juga dapat memperlihatkan posisi relative seseorang diantara teman sekelompoknya. Akan tetapi tidak benar untuk mengatakan bahwa tes dapat memberikan gambaran keseluruhan mengenai seseorang.

\section{Kesimpulan}

Dari hasil penelitian dengan menggunakan uji pearson antara intelegensi dengan hasil belajar matematika diperoleh besarnya koefisien korelasi yaitu 0,752 berarti hubungan intelegensi dengan hasil belajar matematika siswa kelas V SDN 68 Pekanbaru adalah kuat dan searah 
Hubungan Intelegensi dengan Hasil Belajar Matematika Siswa Kelas V SD Negeri 68 Pekanbaru

(positif). Dari persamaan regresi linier sederhana $\hat{Y}=22,74+0,535 X$ terlihat bahwa jika intelegensi meningkat satu satuan maka hasil belajar matematika akan meningkat 0,535 satuan. Besarnya konstribusi (sumbangan) dari variabel intelegensi adalah sebesar $56,6 \%$ sedangkan sisanya 43,4 \% merupakan pengaruh dari faktor lain.

Hasil penelitian ini menunjukkan bahwa $\mathrm{H} 1$ dalam penelitian ini diterima, artinya ada hubungan secara signifikan dari tingkat intelegensi terhadap hasil belajar matematika siswa kelas V SDN 68 Pekanbaru. Faktor intelegensi berpengaruh sangat nyata terhadap prestasi akademik, semakin tinggi intelegensi yang diberikan maka akan semakin tinggi hasil belajar matematika.

Dari hasil pembahasan dan kesimpulan penelitian seperti yang telah diuraikan di atas, maka disarankan sebagai berikut:

1. Intelegensi merupakan salah satu kebutuhan dalam hal prestasi akademik yang perlu di tingkatkan kualitasnya. Maka disarankan agar dapat memperhatikan tingkat intelegensi seseorang dan dapat menerapkan pembelajaran yang baik. Implikasi hasil tes intelegensi terhadap prestasi belajar adalah peran guru (pendidik) dan proses pembelajaran harus ditingkatkan guna meningkatkan prestasi belajar. Proses pembelajaran harus berlangsung dengan baik dan kondusif sebagai upaya memperbaiki dan meningkatkan mutu pembelajaran dikelas. Untuk mewujudkan professional guru dibutuhkan kecerdasan ganda IQ, EQ (kecerdasan emosional) dan SQ (kecerdasan spiritual).

2. Adapun indikator atau petunjuk guru (pendidik) sebagai upaya untuk mencerdaskan siswa adalah berusaha membelajarkan para peserta didik untuk dapat mengembangkan segenap potensi (fitrah) kemanusiaan yang dimilkinya, melalui pendekatan dan proses pembelajaran yang bermakna (Meaningfull Learning) (SQ), menyenangkan (Joyful Learning) (EQ) dan menantang atau problematic (Problematical learning) (IQ), sehingga pada gilirannya dapat dihasilkan kualitas sumber daya manusia Indonesia yang Bagus. Kecerdasan berganda dapat dipelajari dan ditingkatkan kini 
guru (pendidik) musti punya paradigma bagaimana menjadi guru (pendidik) bermartabat dan professional.

3. Perlu untuk disarankan kepada penelitian selanjutnya untuk meneliti faktor-faktor lain yang mempengaruhi prestasi akademik. Dari hasil penelitian diketahui bahwa terdapat faktor-faktor lain yang menentukan prestasi akademik seseorang, seperti penglihatan, pendengaran, minat, bakat, sikap, kesehatan mental, kondisi tempat belajar, sarana dan perlengkapan belajar, materi pelajaran, kondisi lingkungan belajar, dukungan sosial serta pengaruh budaya.

4. Penelitian ini menggunakan teknik analisi regresi sederhana untuk meneliti satu faktor yang mempengaruhi prestasi akademik seseorang. Disarankan untuk penelitian selanjutnya untuk meneliti lebih dari satu fakor yang mempengaruhi prestasi belajar sehingga akan bisa dilihat besarnya pengaruh faktor-faktor lain pada prestasi akademik seseorang.

\section{Daftar Pustaka}

Abu Ahmadi. 2004. Pengaruh dan Minat Belajar Siswa. (Online) http://www.unindra.ac.id/Roida-3.pdf. diakses 13 Desember 2014

Desmita. 2010. Psikologi. Surabaya : Usaha Nasional

Iskandar. 2009. Hubungan Motivasi Belajar dan Hasil Tes Intelegensi. (online) http://eprints.uns.ac.id/4016/1/169662309201010371.pdf. diakses 13 Desember 2014

Lukman Gumadi. 2012. Hubungan Intelegensi Terhadap Prestasi Akademik Taruna. (online). http://www.gunadarma.ac.id/library/articles/graduate/psychology/2 009/Artikel_10504121.pdf diakses 14 Desember 2014

Malik. 2002. Pengaruh Tingkat Intelegensi dan Motivasi Belajar Terhadap Prestasi Belajar. (online). http://www.gunadarma.ac.id/library/articles/graduate/psychology /2009/Artikel_10504121.pdf diakses 14 Desember 2014

Ni Kadek Sukiarti. 2009. Pengaruh Tingkat Intelegensi dan Motivasi Belajar Terhadap Prestasi Akademik. (Online) http://blogspot.com/2009/03/pengaruh-tingkat-intelegensi-danmotivasi-belajar-terhadap-prestasi-akademik.html. Diakses 13 Desember 2014 
Hubungan Intelegensi dengan Hasil Belajar Matematika Siswa Kelas V SD Negeri 68 Pekanbaru

Roida Eva. 2013. Pengaruh Minat dan Kebiasaan Belajar Siswa Terhadap Prestasi Belajar Siswa. (online) http://unindra.ac.id/Roida-3.pdf. diakses 23 Desember 2014

\section{Zetra Hainul Putra}

Dosen Prodi PGSD, FKIP Universitas Riau, Pekanbaru

E-mail: zetra.hainul.putra@lecturer.unri.ac.id

\section{Wulan Sucitra}

Mahasiswa Prodi PGSD, FKIP Universitas Riau, Pekanbaru

E-mail: Wulansucitra5@gmail.com 
Zetra Hainul Putra, Wulan Sucitra 